\title{
BIOGEOCHEMICAL AND MECHANICAL CHARACTERIZATION OF THE LANDFILL FRACTION GENERATED BY MECHANICAL WASTE SORTING
}

\author{
Emelie Andersson, Marit Jobs, Lennart Elfgren and Anders Lagerkvist *
}

Waste Science and Technology, Luleå University of Technology, 97187 Luleå, Sweden

Article Info:

Received:

1 December 2020

Revised:

21 April 2021

Accepted:

3 May 2021

Available online:

30 June 2021

Keywords:

Mechanical separation

Bulky wastes

Construction waste

Landfill mining

\begin{abstract}
When resource recovery from mixed waste streams is performed, new mixed waste streams are generated. Some of these waste streams does not fit well to existing waste management options, for example, they may hold a to low heating value to sustain combustion and they may have a too high carbon content to be accepted at non-hazardous landfills. Also various health and pollution risks may arise as well as practical handling issues due to the physical properties of such wastes. One such waste is the under sieve fraction generated when recovering metals and fuel from mixed waste streams using mechanical and magnetic separation tools. In this work, we examine the properties of one case of mechanical sorting of such under sieve fraction and analyse a broad spectrum of chemical, physical, and mechanical properties as well as some biological. Based on the data we develop recommendations for landfilling, what potential problems might arise and how to counteract them. The content of organic carbon and some trace elements is fairly high, but the biodegradability of the organic content is low and transports of water is also low in the material, especially after compression. We tested a range up to $700 \mathrm{kPa}$. When building a mono fill with this material a special care should be given to dewatering the interior of it to avoid the buildup of water pressure. In summary we think that this material can be safely landfilled.
\end{abstract}

\section{INTRODUCTION}

A range of source separation and waste recovery systems are applied today to the majority of municipal solid waste (MSW) fractions in Sweden, whilst direct landfilling is limited to a small percentage of collected waste. Mixed waste streams such as bulky and construction wastes continue to be landfilled and are typically sorted on-site, mainly into a burnable fuel fraction, and a metallic fraction, which is recycled. The residual under-sieve fraction (see $n .6$ in Figure 1 and Figure 2 for a close-up) is mainly landfilled, at times being subjected to additional treatment. In line with current regulations, a total oxidizable carbon content (TOC) of up to $10 \%$ frequently constitutes the limit beyond which additional treatment should be applied prior to landfilling. In addition to TOC content, other constituents such as chloride leaching or metal content may also indicate the unsuitability of landfilling.

A case study of mechanical separation of a waste stream consisting of mixed bulky household waste and mixed construction wastes was investigated in the context of a master project carried out by Andersson \& Jobs
(2013). The study was performed in 2013 at the landfill of Högbytorp, $40 \mathrm{~km}$ northwest of Stockholm. The results obtained in this study are described here.

On-site procedures included shredding, separation of magnetic materials, and sorting of combustible materials by screening. The equipment used is shown in Figure 1. In this study, the landfilling of a non-magnetic fines fraction from the under-sieve fraction of mechanical sorting (USFMS) is investigated. The total flux of similar materials varies in line with landfill mining activities, construction and demolition activities and collection and handling routines. No standard statistics are available for this treatment residue, although based on case examples it is estimated to be in the order of one Mton/year in Sweden, or about $100 \mathrm{~kg}$ per person per year, an amount comparable to levels reported for the food waste stream.

In this study we aim to cover a broader range of relevant aspects, for the management of this emerging type of waste, than we have seen in previously published literature. Mechanical properties, biodegradability and leaching properties of USFMS were characterized to assess the need for pre-treatment and type of treatment indicated, in addition 
to identifying a need for adaptation of the landfill design to mechanical properties of the waste. More specifically, the following questions were addressed:

1. How high is the pollution potential of USFMS in a landfill environment?

- Degree of biological stability

- Potential contributions to landfill emissions

Potentially beneficial pre-treatment methods

2. How should the properties of USFMS be considered in landfill design and operation?

- Impact on stability (slope stability, settlement etc.)

- Impact on transport of liquid phases

- Influence on installations and treatment systems.

- Implications for aftercare and post-operation usage

\section{MATERIALS AND METHODS}

\subsection{Sampling}

Over a 3-day sampling period, $360 \mathrm{~m}^{3}$ (approx. 180 tons) of USFMS was collected (particle size $<18 \mathrm{~mm}$ ). The USFMS collected over this period represented one month (December - January) of incoming, fresh waste received at the Högbytorp Landfill. An excavator randomly deposited three buckets out of every ten onto a separate pile and left the remaining buckets as spillage. The pile was developed in a linear row and two out of six segments were chosen (giving $180 \cdot(3 / 10) \cdot 2 / 6=18$ tons of USFMS in a separate pile). Inspired by Pierre Gy's Theory of Sampling (Pitard, 1989), an attempt was made to reduce the degrees of freedom when subsampling. Thus, the pile was once again developed linearly and two out of four segments chosen randomly. Finally, one out of three segments was chosen randomly from the remaining row (giving $18 \cdot(2 / 4) \cdot 1 / 3=3$ tons for analysis). For the purpose of further subsampling in the laboratory, the 2D Japanese slab-cake method was applied together with the use of a large riffle splitter. This method emulates the field incremental subsampling process in a controlled laboratory setting: The entire sample is spread evenly onto a $2 \mathrm{D}$ surface at a depth that can be easily penetrated by a square scoop and a scoopful of USFMS representing a vertical column of the slabcake collected and the material placed in a container. This process is repeated at least 30 times at systematic random locations throughout the entire sample (ITRC 2017). Prior to the 3-day sampling period, a visual examination of the fresh, untreated waste was made. Observations made on the test rig are described in more detail in section 2.2.

\subsection{Test rig observations}

The majority of tests and analyses were performed in the test rig shown in Figure 3. Three cylindrical stainless-steel compression vessels with a depth of $0.7 \mathrm{~m}$ and a diameter of $0.5 \mathrm{~m}$ were used.

Compression vessels were filled with $0.07 \mathrm{~m}$ of water-saturated gravel (simulating a drainage layer in a landfill) and a $0.5 \mathrm{~m}$ layer of USFMS (approx. $65 \mathrm{~kg}$ ) placed on top of the gravel, from which it was separated by means of a geotextile. During filling, total solid (TS) content was determined on random samples (100-150 g each) to establish

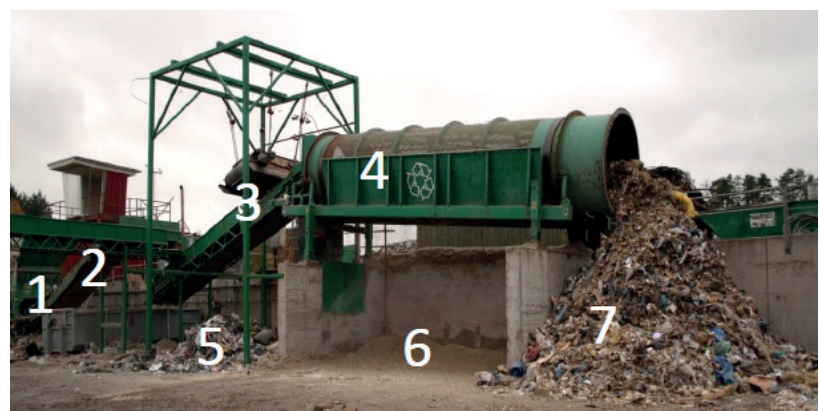

FIGURE 1: Pilot scale equipment for separation of magnetic materials, landfill fraction and fuel fraction. 1) mill, 2) conveyor belt, 3) magnetic separator, 4) drum sieve, 5) magnetic fraction, 6) under sieve fraction, and 7) fuel fraction.

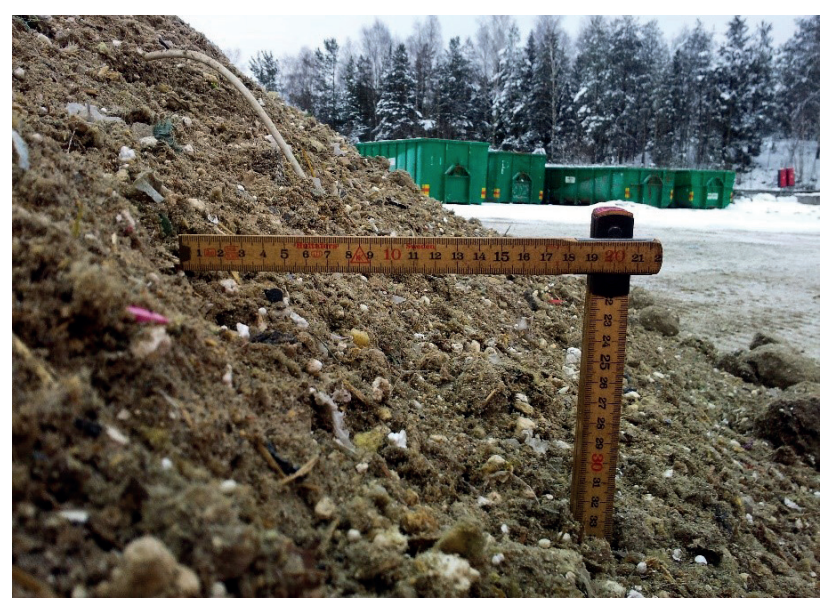

FIGURE 2: The USFMS during sampling and measuring of the angle of repose.

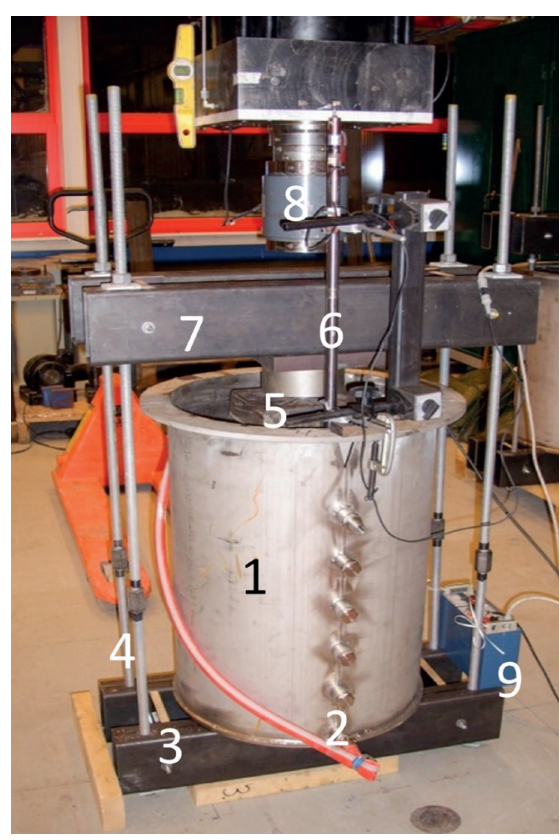

FIGURE 3: Test rig. (1) Compression vessel; (2) Outlet connected to hose; (3) Foundation; (4) Threaded rods; (5) Load cell and metal plate; (6) Linear variable differential transformer (LVDT); (7) Head beam; (8) Servo controlled cylinder, and (9); Driver for LVDT. 
TS content of vessels. Subsequently, vertical compression of up to $700 \mathrm{kPa}$ was applied to vessels to simulate normal stress at the bottom of an approx. 35m deep landfill. A supporting system ensured the maintenance of compression vessels under normal stress conditions of $700 \mathrm{kPa}$ even after compression. However, the supporting system was not capable of maintaining normal stress at constant levels of $700 \mathrm{kPa}$ due to compression in the USFMS. Accordingly, vessel compression was restored to $700 \mathrm{kPa}$ at regular intervals. Six outlets facilitated water influx and leachate sample collection. Compression vessels were also used in determination of porosity, swelling pressure, field capacity, bulk density, dry density and compact density. The following observations were made on the test rig.

\subsubsection{Compression}

The compression test was conducted in the same way as an oedometer test due to lack of a suitable standard. Compression vessels used were larger than those of a standard test and during compression only upward-flow drainage was enabled. Compression was achieved in four steps due to a limited capacity of the servo-controlled cylinder. Compression was applied up to $136 \mathrm{kN}$, corresponding to a normal stress of $700 \mathrm{kPa}$. In the first step, the load was applied at $0.5 \mathrm{~mm} / \mathrm{s}$ up to $13-25 \mathrm{kN}$, and in the second step at $0.5 \mathrm{~mm} / \mathrm{s}$ up to $70 \mathrm{kN}$. The third step was intended to simulate a proctor compactor on a landfill, with load applied in 20 intervals at a range varying from 60 to- $80 \mathrm{kN}$. During the last step, the load was applied at $0.5 \mathrm{kN} / \mathrm{s}$ up to $136 \mathrm{kN}$. Ultimately, USFMS featured a constant load of 136 kN from supporting systems.

To compare compression in the three vessels with values reported in other studies, a compression ratio [Cr] was calculated. The compression ratio corresponded to the slope of the straight line in a diagram where compression [\%] is related to normal stress [kPa] (see Figure 7). Logarithmic scale was not affected by differences in initial porosity.

\subsubsection{Density}

USFMS density was determined as follows: (1) with no load on sampling (2) before, during and after compression in the compression vessels (3) with a proctor compactor test and (4) in the shear boxes after packing.

Bulk density $\rho$ is the ratio between total mass $m$ and total volume $\mathrm{V}$.

$\rho=\frac{m}{V} \quad\left[\mathrm{t} / \mathrm{m}^{3}\right]$

Dry density $\rho_{d}$ is the ratio between dry mass $m_{s}$ and total volume $\mathrm{V}$.

$\rho_{d}=\frac{m_{s}}{V} \quad\left[\mathrm{t} / \mathrm{m}^{3}\right]$

Compact density $\rho_{s}$ is the ratio between dry mass $m_{s}$ and volume of dry mass $\mathrm{V}_{\mathrm{s}}$.

$\rho_{s}=\frac{m_{s}}{V_{s}} \quad\left[\mathrm{t} / \mathrm{m}^{3}\right]$

During sampling, both bulk density and dry density were determined on frozen USFMS. Containers $\left(2 * 1 \mathrm{~m}^{3}\right)$ and beakers $\left(1 * 0.001 \mathrm{~m}^{3}\right)$ were filled and weighed. Dry density was calculated based on observations made following randomized sampling during the process.

Bulk density and dry density were determined in compression vessels prior to start of compression $(0 \mathrm{kPa})$, during the first compression step (65 $\mathrm{kPa})$ and after the fourth compression step (700 kPa). During filling, USFMS mass was weighed and volume measured. Dry density was calculated on random samples. During the second compression step, water started to drain upwards onto the metal plate and water depth was measured following the last compression step; accordingly, density for the second and third steps was not determined. On reaching a compression of $700 \mathrm{kPa}$, calculation of compact density was facilitated due to the presence of water filled pores.

The proctor compaction test complied with SS 27109 standard. Two tests were conducted, one on a wet sample collected from the bottom of the container and one on a drained sample from the container surface.

After packing of the shear boxes, bulk and dry density were determined.

\subsubsection{Unit weight}

Unit weight $\mathrm{y}$ is the ratio between total weight gm and volume V.

$\gamma=\frac{g * m}{V}=g \rho \quad\left[\mathrm{kN} / \mathrm{m}^{3}\right]$

Unit weight was calculated based on bulk densities. Good results were obtained for densities prior to compression, at the first and following the fourth compression steps $(0,65$ and $700 \mathrm{kPa})$. As mentioned previously, during the second and third steps water had started to drain above the metal plate, therefore densities for the second and third compression steps were calculated based on the assumption that water drainage had not occurred. A trendline based on unit weight in the three vessels was calculated.

Unit weight was compared with the findings obtained by Zekkos et al. (2006) and Choudhury \& Savoikar (2009). No swelling pressure was measured due to water drainage from USFMS during compression.

\subsubsection{Permeability tests}

Permeability tests were performed under constant head and upward flow at normal stress $(700 \mathrm{kPa})$. An outlet hose $(\varnothing 2 \mathrm{~cm})$ was installed in the bottom outlet ((2) in Figure 3) of the vessel and connected to a water reservoir through a wall-mounted water hose. The head gradient was determined as the distance between the surface level in the water reservoir and the surface level in the compression vessel. In the upper outlet of the vessels a further hose was installed to collect spillage. After installation, vessels were filled with water. Measurements were undertaken once a clear equilibrium had been reached. The volume of spillage water was measured at intervals of 1 to 3 hours, with the extension of later intervals up to 16 hours. Permeability was determined by means of the equation:

$K=\frac{Q}{A \times I}$

where $\mathrm{K}=$ hydraulic conductivity $[\mathrm{m} / \mathrm{s}] ; \mathrm{Q}=$ water flow 
$\left[\mathrm{m}^{3} / \mathrm{s}\right] ; \mathrm{A}=$ cross-sectional area $\left[\mathrm{m}^{2}\right] ; \mathrm{I}=\mathrm{dH} / \mathrm{dL}=$ hydraulic gradient; $\mathrm{dH}=$ pressure head $[\mathrm{m}]$ and $\mathrm{dL}=$ water column [m].

A mean daily value was calculated for each vessel. The test lasted for a total of 20 days and a mean value of permeability was subsequently estimated from the mean value of each compression vessel.

\subsubsection{Field capacity}

Field capacity FC was determined by measuring the amount of water discharged above the metal plate ((5) in Figure 3) at maximum normal stress (700 kPa). The amount of free water (i.e. field capacity) retained by the USFMS at $700 \mathrm{kPA}$ was estimated by subtracting the amount of water above the metal plate from the amount of water contained in the USFMS prior to compression. A mean value for field capacity was estimated from the mean value for each compression vessel.

$F C=\frac{m_{w}}{m_{d}}$

where $\mathrm{FC}=$ mass of free water per kg of dry weight [kg water $/ \mathrm{kg}$ TS]; $m_{w}=$ mass of free water $[\mathrm{kg}] ; \mathrm{m}_{\mathrm{d}}=$ dry mass $[\mathrm{kg}]$.

\subsubsection{Porosity}

Porosity was measured at $700 \mathrm{kPa}$ at known input values of TS (\%). All pores were assumed as being water saturated. Water volume in the vessel at $700 \mathrm{kPa}$ was calculated by subtracting the volume of water discharged above the metal plate from the total volume of water prior to compression. Porosity was then estimated by

$n=\frac{V_{p}}{V}$

where $n=$ porosity $[-], v_{p}=$ pore volume $\left[\mathrm{m}^{3}\right]$ and $v=$ total volume of USFMS $\left[\mathrm{m}^{3}\right]$.

Three months after compression, a comparative value of porosity was calculated.

\subsection{Other tests and analyses}

\subsubsection{Standard tests used}

Table 1 shows the material properties of USFMS that were examined using standardized methods. Other testing proceedures are briefly described under 2.3.2-2.3.7.

\subsubsection{Shear strength}

Shear strength was determined by means of a direct shear test. The shear boxes had a size of $0.24 * 0.26 * 0.14 \mathrm{~m}$ and were packed with approximately $14-15 \mathrm{~kg}$ of USFMS. Three direct shear tests were carried out at three different normal stresses; 200, 300 and $400 \mathrm{kPa}$ and the shear applied perpendicular to packed layers. To calculate shear strength, shear failure was assumed to occur at a deformation of $25 \mathrm{~mm}$ (although the test was carried out up to a deformation of $30 \mathrm{~mm}$ ). The shear strength envelope with cohesion intercept (c) and friction angle $(\varphi)$ was calculated according to the Mohr-Coulomb failure criterion.

The Mohr-Coulomb failure criterion may be expressed as an equation for the line representing the failure envelope. The general equation is:

$\tau_{f}=c+\sigma_{f} \cdot \tan \phi$

where $\tau_{f}=$ shear stress on the failure plane

$\mathrm{c}=$ apparent cohesion

$\sigma_{f}=$ normal stress on the failure plane

$\varphi=$ angle of internal friction

\subsubsection{Angle of repose}

During subsampling the angle of repose was determined trigonometrically on three heaps of $360 \mathrm{~m}^{3}$ frozen UFSFM.

\subsubsection{Soil gradation}

Based on results obtained from the dry and wet sieve the uninform coefficient $(\mathrm{Cu})$ was calculated by:

$C u=\frac{d_{60}}{d_{10}}$

where $d_{60}$ is the grain diameter at $60 \%$ passing and $d_{10}$ is the grain diameter at $10 \%$ passing.

\subsubsection{Column test}

On reaching a $700 \mathrm{kPa}$ load, water was added at the bottom of the models and leachate collected from each vessel through the third to bottom outlet. L/S ratio was calculated to be approx. 0.6.

\subsubsection{Agitation batch tests (standard leaching test)}

In addition to permeability measurements in the com-

TABLE 1: Standard tests used.

\begin{tabular}{|c|c|}
\hline Property tested & Method id \\
\hline \multicolumn{2}{|c|}{ Mechanical characterization } \\
\hline \multirow[t]{2}{*}{ Grain size distribution } & Dry sieving (SS-ISO 11277) \\
\hline & Wet sieving (SS-EN 933-1) \\
\hline Density & Proctor compactor (SS 027109) \\
\hline \multicolumn{2}{|c|}{ Biogeochemical characterization } \\
\hline \multirow[t]{2}{*}{ Total content } & Total solids, TS (SS-EN 14346) \\
\hline & $\begin{array}{l}\text { Volatile solids, VS (SS-EN 15169) } \\
\text { Total organic carbon, TOC; Total carbon, TC; Total incinerated carbon, TIC (SS-EN 13137), } \\
\text { Total content of elements Modified EPA methods } 200.7 \text { (US EPA, 1994a) and } 200.8 \text { (US EPA, 1994b) were used } \\
\text { for the total element composition analysis with ICP-AES/SFM }\end{array}$ \\
\hline Leaching properties & Agitation batch test, (L/S 10) (SS-EN 12457-4) \\
\hline
\end{tabular}


pression vessels, agitation batch tests were also performed at a liquid/solid ratio of L/S 10. Tests complied with Swedish standards, but were modified for use under anaerobic conditions by adding $0.7 \mathrm{~g}$ of $1 \%$-methanol prior to agitation. The amount of methanol required to consume oxygen in $500 \mathrm{ml}$ of water was calculated by: $2 \mathrm{CH}_{3} \mathrm{OH}+$ $\mathrm{O}_{2} \leftrightarrow 2 \mathrm{HCHO}+2 \mathrm{H}_{2} \mathrm{O}$.

The bottles were sealed with butyl rubber stoppers, air was expelled and replaced by nitrogen gas. The bottles were stored in a dark place for two days before agitation. Leachate was collected using an injection needle and directly filtered before analysis.

\subsubsection{Gas potential}

Gas potential was determined indirectly by promoting complete mineralization, assessing chemical oxidation, and measurement of direct biochemical methane potential (BMP). Complete mineralization of USFMS was achieved in a bomb calorimeter, whilst chemical oxidation was evaluated through determination of COD. COD content was measured after blending USFMS with water to an L/S ratio of 100 , which was then mixed and homogenized. COD content in $2 \mathrm{ml}$ of water after 24 hours agitation was analyzed in a COD Cell Test (MERCK).

Biological degradability was assessed by means of biochemical methane production assays (BMP) using 18 glass bottles $(120 \mathrm{ml})$ prepared with inoculum and substrate (USFMS) at a ratio of 1:1, 1:2 and 2:1, respectively (based on g VS). Total volume of inoculum and substrate in each bottle was approx. $50 \mathrm{~g}$. To optimize degradation, the mixture was crushed and homogenized before bottles were filled. Anaerobic conditions were achieved by sealing the bottles with butyl rubber stoppers. BMP test was carried out at a temperature of $30^{\circ} \mathrm{C}$ and $55^{\circ} \mathrm{C}$ ( 9 bottles at each temperature). At both temperatures, 3 blank tests were performed with bottles containing inoculum alone. The volume of produced gas was measured until gas production was negligible.

All observations for organic content were compared using corresponding amounts of methane. For this purpose, the calorific value of methane was used as comparison with the measured heating value of the material; a $40 \%$ assumed carbon content and 0 carbon oxidation state were adopted as comparison with VS, using the same assumed oxidation in conversion of TOC values to carbon; COD was merely taken as four-fold the $\mathrm{CH}_{4}$ mass. The $\mathrm{CH}_{4}$ content of formed gas was assumed to be $50 \%$.

\section{RESULTS AND DISCUSSION - POLLUTION POTENTIAL}

The biogeochemical properties of USFMS, i.e. degree of biological stability and potential landfill emissons, are of importance when discussing the materials pollution potential. These aspects should also be taken into account when considering beneficial pre-treatment methods.

\subsection{Is the waste biologically stable?}

The observations made regarding organic content are illustrated in Table 2 together with an estimation of corresponding methane potential based on related properties.

This is for comparison and for illustrating the character of the material. The methane amounts have been determined from the other observations as; $\mathrm{COD} / 4=\mathrm{CH}_{4}(\mathrm{~g} / \mathrm{g})$ and from the heating value by deviding by that of $\mathrm{CH}_{4}$. VS and TOC values can be compared to establish carbon content of the material. Assuming that a mean oxidation of the carbon corresponds to zero $\mathrm{VS}^{*} 0.3^{*} 16 / 12=\mathrm{VS} * 0.4=\mathrm{CH}_{4}$. The corresponding amount of methane estimated from the TOC value will be TOC/2* $16 / 12$.

The data obtained however raises a few issues, namely, COD is lower than TOC and COD/ BMP ratio corresponds to approx. $25 \%$ of expected values. In spite of the highly variable material and small analytical samples, the majority of observations fall into a fairly narrow range when expressed as corresponding methane amounts, with the exception of COD and BMP. In both cases, these values reflect the fate of solubilized organics, which hint at a limited rate of solubilization of the material. When assessing data quality, observations made for VS are those most likely to reliably reflect the amount of organic material available, particularly as the largest samples with the lowest degree of inter-sample variation were used for VS measurement.

The marked variation of VS in line with temperature highlights the scarce volatilization of the material. Moreover, heating value is low in comparison to TOC and VS, possibly due to the presence in the material of flame retarding substances such as PVC. Thermal stability is also an indicator of low biodegradability.

A COD/TOC ratio of approx. 0.6 was detected, low-

TABLE 2: Average observations related to organic material and corresponding calculated amount of methane. $\mathrm{N}=3$.

\begin{tabular}{|c|c|c|c|c|}
\hline Component & Unit & Average & Standard dev & $\begin{array}{c}\mathrm{CH}_{4} \text {-calc } \\
\mathrm{g} / \mathrm{kg} \text { TS }\end{array}$ \\
\hline COD & $\mathrm{g} / \mathrm{kg}$ TS & 90.59 & 22.2 & 23 \\
\hline TOC & $\mathrm{g} / \mathrm{kg}$ TS & 151.4 & 43.8 & 101 \\
\hline VS $550^{\circ} \mathrm{C}$ & $\mathrm{g} / \mathrm{kg}$ TS & 146.5 & 5.06 & 60 \\
\hline VS $750^{\circ} \mathrm{C}$ & $\mathrm{g} / \mathrm{kg} \mathrm{TS}$ & 178.4 & 5.98 & 73 \\
\hline VS $925^{\circ} \mathrm{C}$ & $\mathrm{g} / \mathrm{kg} \mathrm{TS}$ & 180 & 6.01 & 74 \\
\hline VS $1000^{\circ} \mathrm{C}$ & $\mathrm{g} / \mathrm{kg}$ TS & 246 & 2.58 & 101 \\
\hline Heating value & $\mathrm{MJ} / \mathrm{kg} \mathrm{TS}$ & 2.98 & 1.06 & 60 \\
\hline BMP & I/kg TS & 31.5 & 1.4 & 23 \\
\hline
\end{tabular}


er therefore than the ratio obtained for any organic substance, with a typical range exceeding 2 up to a maximum for methane of 5.33. This is a further indication that only a fraction of the organic material was actually oxidized in the test environment. USFMS therefore may be classified as an almost stable waste, although featuring a high carbon content.

\subsection{To what extent does the waste contribute to landfill emissions?}

Bearing in mind the variations in sampling and analytical procedures, the findings obtained indicated that a prevalent share of the material was comprised of scarcely degradable polymers with a high carbon content. Thus, in an anaerobic landfill environment the material degrades very slowly, with the resulting methane emissions approx. one order of magnitude lower than those yielded by mixed household waste. Thus, passive treatment methods such as design of the landfill cover to act as a suitable habitat for methane oxidizing biota, may be sufficient to reduce methane emissions.

The compressed material however features low permeability, thus implying that even slight gas generation may result in substantial pressure build-up. Accordingly, it would be prudent to add a series of vertically-connected drainage layers throughout the landfill body to allow for the release of pressure and channeling of the gas generated to methane oxidation areas.

The total content of several hazardous trace elements (As, Ba, Cr, Cu, Ni, V, Zn) was higher than that reported in previous studies performed on excavated and screened

TABLE 3: Total content of elements ( $\mathrm{mg} / \mathrm{kg}$ TS) in USFMS (mean value based on 3 samples). Values marked by red and red bold type indicates the exceeding of Swedish EPA guideline values for sensitive and less sensitive land use, respectively. Concentrations obtained in previous studies are listed in right-hand columns.

\begin{tabular}{|c|c|c|c|}
\hline Element & USFMS & \pm & $($ (IWCS, 2009)1) \\
\hline TS (\%) & 51.3 & 2.55 & \\
\hline As & 31.7 & 19.1 & $2.0-7.8$ \\
\hline $\mathrm{Ba}$ & 1167 & 425.7 & $98-265$ \\
\hline $\mathrm{Be}$ & 0.97 & 0.053 & $0.10-0.21$ \\
\hline $\mathrm{Cd}$ & 1.76 & 0.305 & $1.4-8.0$ \\
\hline Co & 14.6 & 5.41 & $0.8-2.0$ \\
\hline $\mathrm{Cr}$ & 151 & 47.4 & $12.8-35.9$ \\
\hline $\mathrm{Cu}$ & 1116 & 1299 & $19.0-96.5$ \\
\hline $\mathrm{Hg}$ & 0.279 & 0.135 & $0.03-0.35$ \\
\hline Mo & 4.47 & 2.88 & \\
\hline $\mathrm{Nb}$ & 6.31 & 0.842 & \\
\hline $\mathrm{Ni}$ & 88.2 & 32.8 & $7.7-43.4$ \\
\hline $\mathrm{Pb}$ & 274 & 107 & $9.7-900$ \\
\hline S & 15758 & 23296 & \\
\hline V & 48.2 & 5.64 & $9.4-17$ \\
\hline $\mathrm{Zn}$ & 1490 & 260 & $130-680$ \\
\hline
\end{tabular}

1) Analysis performed on 8 samples after screening ( $<25.4 \mathrm{~mm}$ ) of excavated waste from a depth of approx. $4.6 \mathrm{~m}$ in Perdido Landfill, Florida. waste (Table 3). The lower concentrations found in other studies could be due to the presence of sand and gravel from daily cover in landfilled and excavated waste. Due to a lack of relevant studies in literature, no comparison of the metal content in fresh USFMS was possible. Several elements (As, Ba, Cr, Cu, Zn) also exceeded Swedish EPA guideline values relating to the less sensitive use of land. A large inter-sample variation was observed, and in some cases ( $\mathrm{Cr}, \mathrm{Cu}$ and $\mathrm{S}$ ), a heavily skewed distribution.

The results of leaching tests are shown in Tables 4 and 5 and Figures 4 and 5 . The elements exceeding threshold values for disposal of waste in a Swedish class 2 landfill (non-hazardous landfill) were $\mathrm{Sb}$ and $\mathrm{Zn}$. Calculations revealed that the various concentrations obtained at $\mathrm{L} / \mathrm{S}$ ratio 10 corresponded to $0.1-5.3 \%$ of the total content, excluding Mo, Sb and S (92.5; 21.7 and $39.5 \%$ respectively). In addition to $\mathrm{Sb}$ and $\mathrm{Zn}$, the only element exceeding threshold values for disposal of waste is DOC - a result which, combined with a TOC of $15.1 \%$ probits landfilling of the material. The organic material content of USFMS, both total content and dissolved in leachate, tends to indicate another source of emission. Runoff water collected during thawing featured similar concentrations of elements to leachate at L/S 0.6. Drainage water will need to be collected and treated to prevent emissions from impervious surfaces.

The difference in concentration of $\mathrm{Cl}$ at L/S ratio 0.6

TABLE 4: Concentration of elements in leachate (mean value based on 3 samples) from column test (L/S ratio 0.6 ) in compression vessels ( $\varnothing 0.5 \mathrm{~m}$ ) at normal stress $700 \mathrm{kPa}$. Values marked in red exceeds threshold limits for disposal of waste in Swedish class 2 landfill (non-hazardous landfill).

\begin{tabular}{|c|c|c|c|c|}
\hline Element & Unit & USFMS L/S 0.6 & {$[ \pm]$} & $c_{0}(L / S 0,1)^{1)}$ \\
\hline Al & $\mu \mathrm{g} / \mathrm{l}$ & 246 & 57.9 & \\
\hline As & $\mu \mathrm{g} / \mathrm{l}$ & 27.9 & 10.2 & 300 \\
\hline $\mathrm{Ba}$ & $\mu \mathrm{g} / \mathrm{l}$ & 368 & 47.2 & 20000 \\
\hline $\mathrm{Cd}$ & $\mu g / l$ & 1.55 & 0.100 & 300 \\
\hline Co & $\mu g / l$ & 103 & 14.6 & \\
\hline $\mathrm{Cr}$ & $\mu g / l$ & 40.8 & 5.12 & 2500 \\
\hline $\mathrm{Cu}$ & $\mu g / l$ & 104 & 28.9 & 30000 \\
\hline $\mathrm{Hg}$ & $\mu \mathrm{g} / \mathrm{l}$ & 0.355 & 0.03 & 30 \\
\hline $\mathrm{Mn}$ & $\mu g / l$ & 9377 & 1301 & \\
\hline Mo & $\mu g / l$ & 156 & 55.1 & 3500 \\
\hline $\mathrm{Ni}$ & $\mu \mathrm{g} / \mathrm{l}$ & 479 & 119 & 3000 \\
\hline $\mathrm{Pb}$ & $\mu g / l$ & 24.0 & 1.60 & 3000 \\
\hline $\mathrm{Sb}$ & $\mu g / l$ & 77.2 & 7.47 & 150 \\
\hline $\mathrm{Se}$ & $\mu \mathrm{g} / \mathrm{l}$ & 6.05 & 1.79 & 200 \\
\hline $\mathrm{Zn}$ & $\mu g / l$ & 9960 & 1760 & 15000 \\
\hline $\mathrm{Cl}$ & $\mathrm{mg} / \mathrm{l}$ & 1720 & 255 & 8500 \\
\hline $\mathrm{F}$ & $\mathrm{mg} / \mathrm{l}$ & $<0.500$ & - & 40 \\
\hline $\mathrm{SO}_{4}$ & $\mathrm{mg} / \mathrm{l}$ & 2067 & 176 & 7000 \\
\hline DOC & $\mathrm{mg} / \mathrm{l}$ & 4150 & 771 & 250 \\
\hline P-tot & $\mathrm{mg} / \mathrm{l}$ & 0.463 & 0.249 & \\
\hline
\end{tabular}

1) 30 § NFS 2004:10 (Swedish EPA. 2004) 
TABLE 5: Concentration of elements (mg/kg TS) in USFMS leachate from agitation batch tests (L/S ratio 10) under anaerobic conditions (mean value based on 3 samples). Anaerobic conditions were obtained by the addition of methanol $(0.007 \mathrm{ml} / 500 \mathrm{ml}$ of water). Values marked in red indicates the exceeding of threshold limits for disposal of waste in a Swedish class 2 landfill (non-hazardous landfill).

\begin{tabular}{|c|c|c|c|}
\hline Element & USFMS L/S 10 & \pm & $c_{0}(L / S 10)^{1)}$ \\
\hline Al & 3.18 & 0.392 & \\
\hline As & 0.657 & 0.0591 & 2 \\
\hline $\mathrm{Ba}$ & 9.57 & 0.224 & 100 \\
\hline $\mathrm{Cd}$ & 0.0152 & 0.00119 & 1 \\
\hline Co & 0.350 & 0.0291 & \\
\hline $\mathrm{Cr}$ & 0.289 & 0.00934 & 10 \\
\hline $\mathrm{Cu}$ & 1.14 & 0.114 & 50 \\
\hline $\mathrm{Hg}$ & 0.00536 & 0.000116 & 0.2 \\
\hline $\mathrm{Mn}$ & 56.7 & 4.57 & \\
\hline Mo & 4.13 & 0.0911 & 10 \\
\hline $\mathrm{Ni}$ & 1.70 & 0.0497 & 10 \\
\hline $\mathrm{Pb}$ & 0.642 & 0.0297 & 10 \\
\hline $\mathrm{Sb}$ & 3.44 & 0.0623 & 0.7 \\
\hline $\mathrm{Se}$ & 0.232 & 0.00469 & 0.5 \\
\hline $\mathrm{Zn}$ & 79.7 & 9.99 & 50 \\
\hline $\mathrm{SO} 4$ & 17984 & 44.2 & 20000 \\
\hline $\mathrm{Cl}$ & 1358 & 3.79 & 15000 \\
\hline $\mathrm{F}$ & $<5.25$ & 0.0207 & 150 \\
\hline DOC & 1963 & 63.6 & 800 \\
\hline P-tot & 6.46 & 0.155 & \\
\hline
\end{tabular}

and 10 , respectively, corresponds to the difference in dilution between the two tests. Likewise, redox-sensitive elements such as $\mathrm{Cr}$, Co and $\mathrm{Fe}$, also display differences in concentration corresponding to difference in dilution. Thus, redox-sensitive elements are reduced to a similar degree in both tests, with methanol addition being assumed to have acted as a reduction agent for oxygen in the agitation batch test.

Emission potential is present in both gas and liquid phases; however, given the slow degradation rate and low permeability of the material, only low intensity emissions are expected, which may promote the use of passive treatment methods. The exception would be run-off from surfaces on which shredding and intermediate material storage is carried out.

\subsection{Potentially beneficial pre-treatment methods}

The separation of degradable organics could be improved by additional processing, although costs may rise beyond the impact produced. Additional treatments such as washing or hydrothermal carbonation could be considered.

Taking into account the biogeochemical properties of USFMS, there may be a small potential for bioconversion, although the limited permeability would render composting largely inefficient. Application therefore of a simple form of biological treatment would not appear to be a feasible option.

Other options may include chemical oxidation, electro techniques or mixing with stabilizers, e.g. washing dust from gravel production. These options would all be possible, although the implicated costs may be prohibitive.

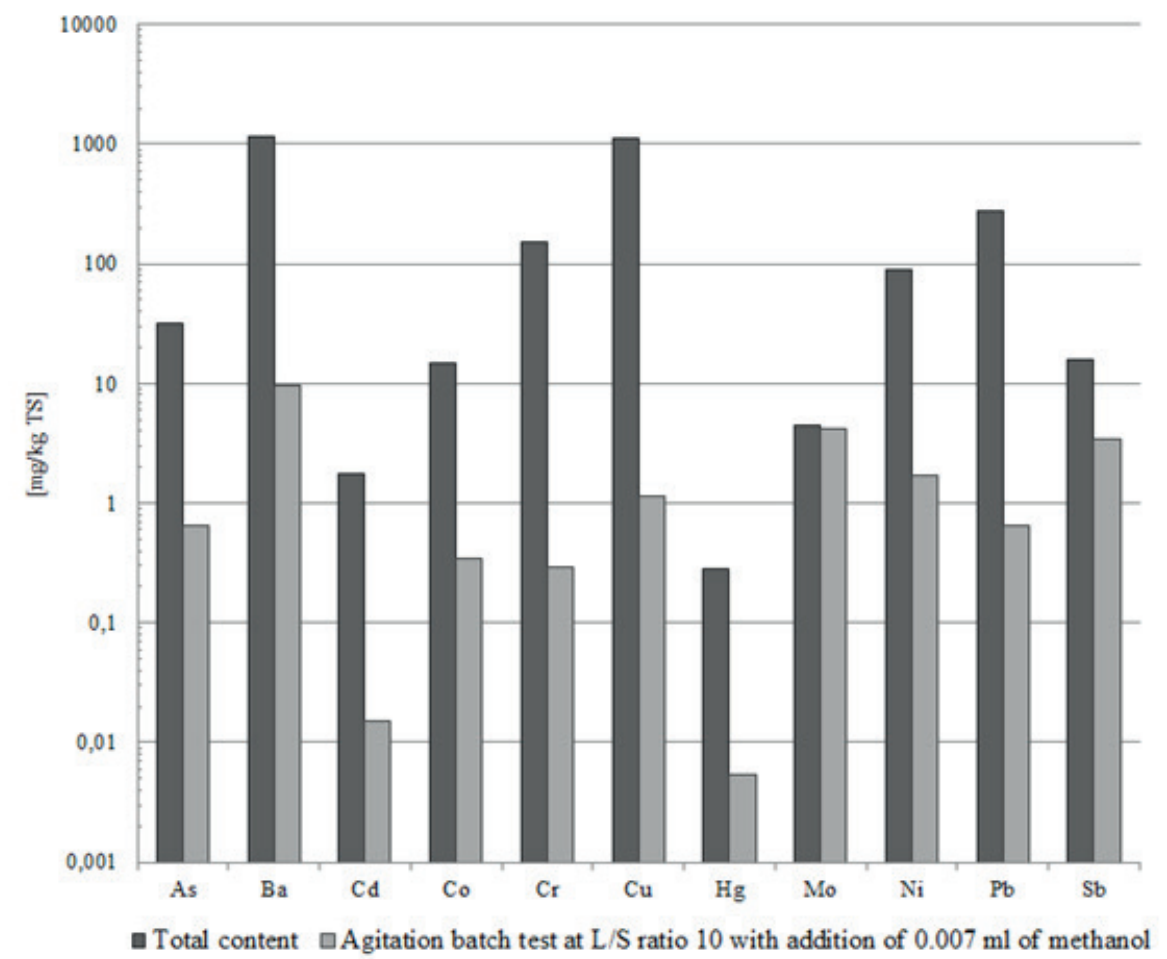

FIGURE 4: Concentration of elements in USFMS leachate at L/S ratio 10 compared to the total content in USFMS. Methanol was added to achieve anaerobic conditions in sample bottles. 


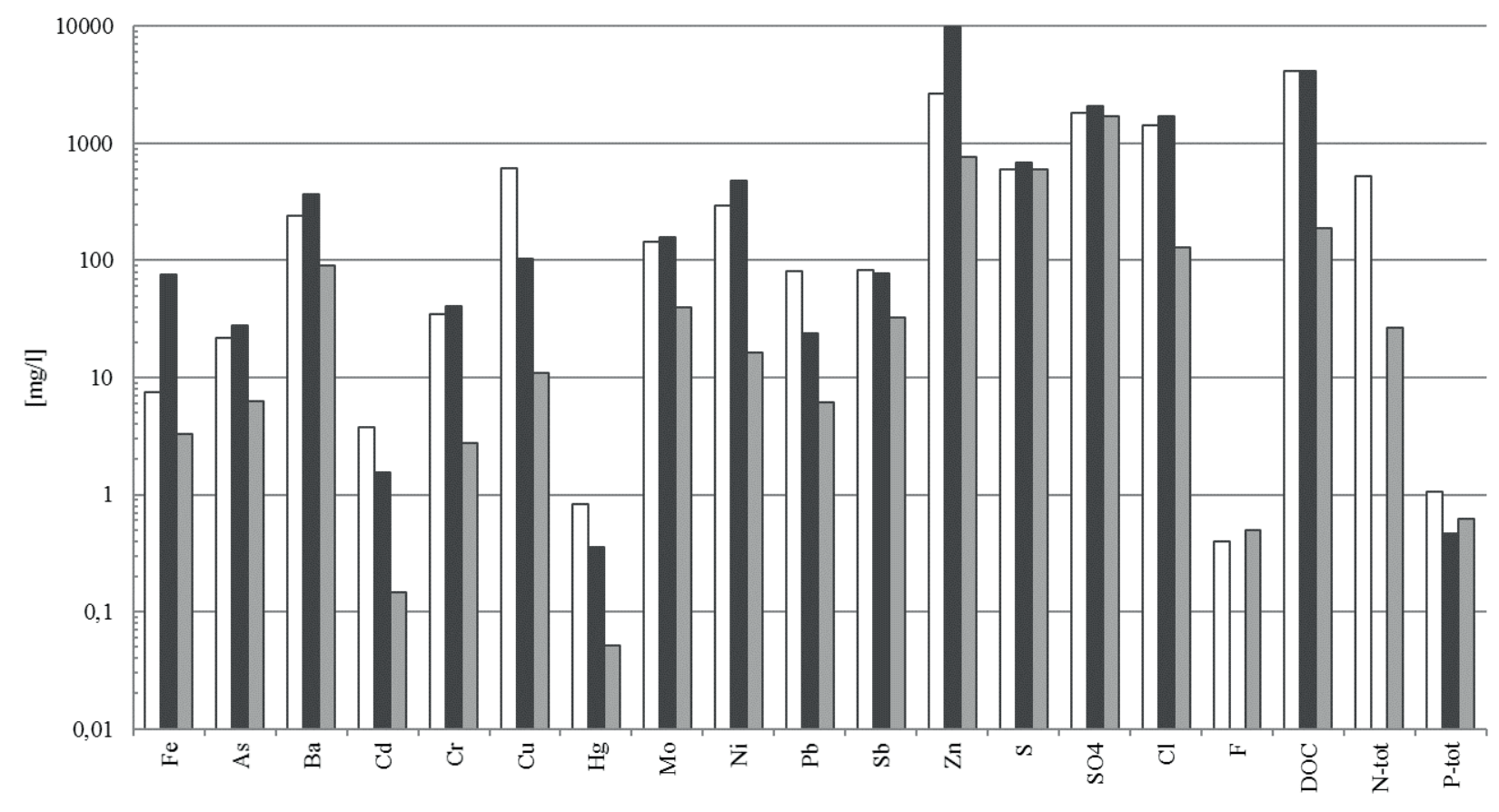

口Water from impervious surfaces $\quad$ C Column test $\mathrm{L} / \mathrm{S} 0,6 \quad \square$ Agitation batch test $\mathrm{L} / \mathrm{S} 10$ (addition of $0.007 \mathrm{ml} \mathrm{methanol} / 500 \mathrm{ml}$ of water)

FIGURE 5: Concentration of elements in leachate from USFMS; water from impervious surfaces ( 1 sample, filtered), leachate from column test at L/S ratio 0.6 (3 samples, non-filtered) and leachate from agitation batch test at L/S ratio 10 (3 samples, filtered).

\section{RESULTS AND DISCUSSION - LANDFILL DESIGN AND OPERATION}

The mechanical properties of USFMS, capable of impacting on slope stability, settlement, water-holding capacity and permeability, should be taken into account when designing and operating a landfill. Some of the more critical aspects are discussed below.

\subsection{Mechanical properties}

A summary of the results of mechanical tests are shown in Table 6.

\subsection{Impact on stability}

\subsubsection{Slope stability}

If shear stress is higher than shear strength, slope failure may occur. Shear strength is largely dependent on three factors: (1) friction in the contact surface between individual particles, (2) wedging of particles and (3) adhesion between particles (SGI, 2007). Accordingly, in an MSW landfill shear strength is influenced by waste composition, degree of compaction, daily cover, moisture conditions, age, leachate management and overburden pressure.

Test results reveal how the shear strength envelope of USFMS is governed by a cohesion intercept $\mathrm{c}=26 \mathrm{kPa}$ and friction angle $\varphi=47^{\circ}$, see Figure 6 . Shear tests were performed up to a horizontal shear displacement of $30 \mathrm{~mm}$, without producing any shear failure. According to Stark et al. (2009), shear failure was assumed to occur at $25 \mathrm{~mm}$, as is routine for underlying soils or sealing layers. In this study, the shear test was performed perpendicular to packing layers, thus preventing measurement of critical shear strength. In previous studies, (Zekkos, 2010; Reddy et al., 2009; Stark et al., 2009) the cohesion intercept c generally ranged from $6-30 \mathrm{kPa}$ and the friction angle $\varphi$ ranged from $30-35^{\circ}$. Therefore, in the present study the cohesion intercept is at the high end of a normal range, whilst the friction angle is higher. Figure 6 show shear strength of the USFMS compared to models of shear strength reported in previous studies. Hossain et al. (2009) demonstrated a reduction in the friction angle at a lower R-value, where R-value is represented by particle size/equipment size ratio. A study by Dewaele et al. (2011) showed a reduction in cohesion intercept after landfill mining and out-sorting of larger items. A lower shear strength would be expected for USFMS, subjected to milling, compared to untreated MSW.

The high friction angle in the shear strength envelope may be explained by grain size distribution and waste composition. Result obtained for grain size distribution by wet sieve highlighted a small grain size distribution (45\% gravel, $35 \%$ sand and $20 \%$ silt) with a high uniform coefficient (Cu40), see Figure 11 and 12. A material with a high uniform coefficient is evenly distributed between different grain sizes, thus allowing smaller grains to fill the voids between larger grains. This contributes to a more stable structure which produces a positive effect on shear strength. Shredding may also result in edgy particles which contribute to increased friction between the particles. The material itself contains fibrous material with a high specific surface, such as mineral heat insulation products. Fibrous and edgy particles add to the shear strength. Wood splinters, wires, etc. protruding from the failure planes were observed. In conclusion therefore, the risk of slope failure appears to be lower for this type of material than for ordinary MSW.

Dry density is used as a measure of the degree of com- 
TABLE 6: Mechanical properties (Standard deviations are given in brackets).

\begin{tabular}{|c|c|}
\hline Mechanical property & Result \\
\hline Angle of repose & $31.7^{\circ}( \pm 2.29)$ \\
\hline Grain size distribution & $\begin{array}{l}\text { Dry sieve } \\
45 \% \text { gravel. } 50 \% \text { sand. } 5 \% \text { silt. Cu20 } \\
\text { Wet sieve } \\
45 \% \text { gravel. } 35 \% \text { sand. } 20 \% \text { silt. Cu} 40\end{array}$ \\
\hline Shear strength & $\mathrm{c}=26 \mathrm{kPa} \cdot \varphi=47^{\circ}$ \\
\hline Compression ratio & $C_{r}=0.19( \pm 0.006)$ \\
\hline Density & $\begin{array}{l}\text { 1. During sampling } \\
\rho=0.62 \mathrm{t} / \mathrm{m}^{3}( \pm 0.07) \cdot \rho_{d}=0.29 \text { ton } / \mathrm{m}^{3}( \pm 0.03) \\
\text { TS } 47.1 \% \\
\text { 2. Compression test } \\
\rho=0.68 \mathrm{t} / \mathrm{m}^{3}( \pm 0.05) \cdot \rho_{d}=0.42 \mathrm{ton} / \mathrm{m}^{3}( \pm 0.03) \text { at } 0 \mathrm{kPa} \\
\rho=0.92 \mathrm{t} / \mathrm{m}^{3}( \pm 0.1) \cdot \rho_{\mathrm{d}}=0.59 \mathrm{t} / \mathrm{m}^{3}( \pm 0.06) \text { at } 65 \mathrm{kPa} \\
\rho=1.55 \mathrm{t} / \mathrm{m}^{3}( \pm 0.06) \cdot \rho_{\mathrm{d}}=1.02 \mathrm{ton} / \mathrm{m}^{3}( \pm 0.04) \rho_{\mathrm{s}}=2.20 \mathrm{ton} / \mathrm{m}^{3}( \pm 0.2) \text { at } 700 \mathrm{kPa} \\
\text { TS } 62.2 \% \\
\rho=1.50 \mathrm{t} / \mathrm{m}^{3}( \pm 0.0) \cdot \rho_{\mathrm{d}}=1.01 \mathrm{ton} / \mathrm{m}^{3}( \pm 0.03) \rho_{\mathrm{s}}=2.01 \mathrm{ton} / \mathrm{m}^{3}( \pm 0.05) \text { at } 700 \mathrm{kPa} \text { for three months } \\
\text { TS } 66 \% \\
\text { 3. Proctor compactor test } \\
\rho=1.37 \mathrm{t} / \mathrm{m}^{3} \cdot \rho_{\mathrm{d}}=0.67 \mathrm{t} / \mathrm{m}^{3} \cdot \rho_{\mathrm{s}}=2.14 \text { at } 500 \mathrm{~kJ} / \mathrm{m}^{3} . \\
\text { TS } 48.73 \% \\
\rho=0.7 \mathrm{t} / \mathrm{m}^{3} \cdot \rho_{\mathrm{d}}=0.51 \mathrm{t} / \mathrm{m}^{3} \text { at } 500 \mathrm{~kJ} / \mathrm{m}^{3} . \mathrm{TS} 64.57 \% \\
\text { 4. Shear test } \\
\rho=1.56( \pm 0.06) \mathrm{t} / \mathrm{m}^{3} \cdot \rho_{\mathrm{d}}=1.01( \pm 0.05) \mathrm{t} / \mathrm{m}^{3} \text { at after shear box packing at TS } 64.9 \%\end{array}$ \\
\hline Porosity & $\begin{array}{l}n=53.98 \%( \pm 2.09) \text { at } 700 \mathrm{kPa} \\
\mathrm{n}=49.82 \%( \pm 3.04) \text { at } 700 \mathrm{kPa} \text { for three months }\end{array}$ \\
\hline Field capacity & $54( \pm 0.2) \%$ \\
\hline Permeability & $6.7 \times 10^{-9}\left( \pm 2.5 \times 10^{-9}\right) \mathrm{m} / \mathrm{s}$ \\
\hline
\end{tabular}

paction in shear boxes. There was no significant difference between dry densities in the three shear boxes, with density before shearing being almost as high as dry density measured after compaction to $700 \mathrm{kPa}$. The material in hear boxes may have been over consolidated (I e the material has earlier been exposed to higher normal stresses) before shearing and the resulting measured shear strength overestimated; maximum shear strength was not however reached during the shear test.

During compression, USFMS was found to be water saturated during the second compression round (from 67- 135 $\mathrm{kPa}$ to $360 \mathrm{kPa}$ ), thus implying release of water from USFMS under pressure. No swelling pressure was observed.
TS (47 $\pm 6 \%)$ was lower in USFMS as compared to previous studies on excavated and screened landfill fractions (Dewaele, 2011). It should however be noted that TS was determined for USFMS samples collected at temperatures below $0^{\circ} \mathrm{C}$, and therefore considered as "frozen" material, likely to hold more water than a thawed drained sample. For drained USFMS, TS of $64 \pm 1.7 \%$ was determined, therefore in the same range as TS for fresh MSW. Visual examination revealed a high content of absorbing materials (madrasses, isolation etc.) in USFMS, which likely explains the low TS obtained when frozen. It is reasonable to assume that in a future landfill TS will be subject to seasonal variations due to rain storms, dry winters etc. The results

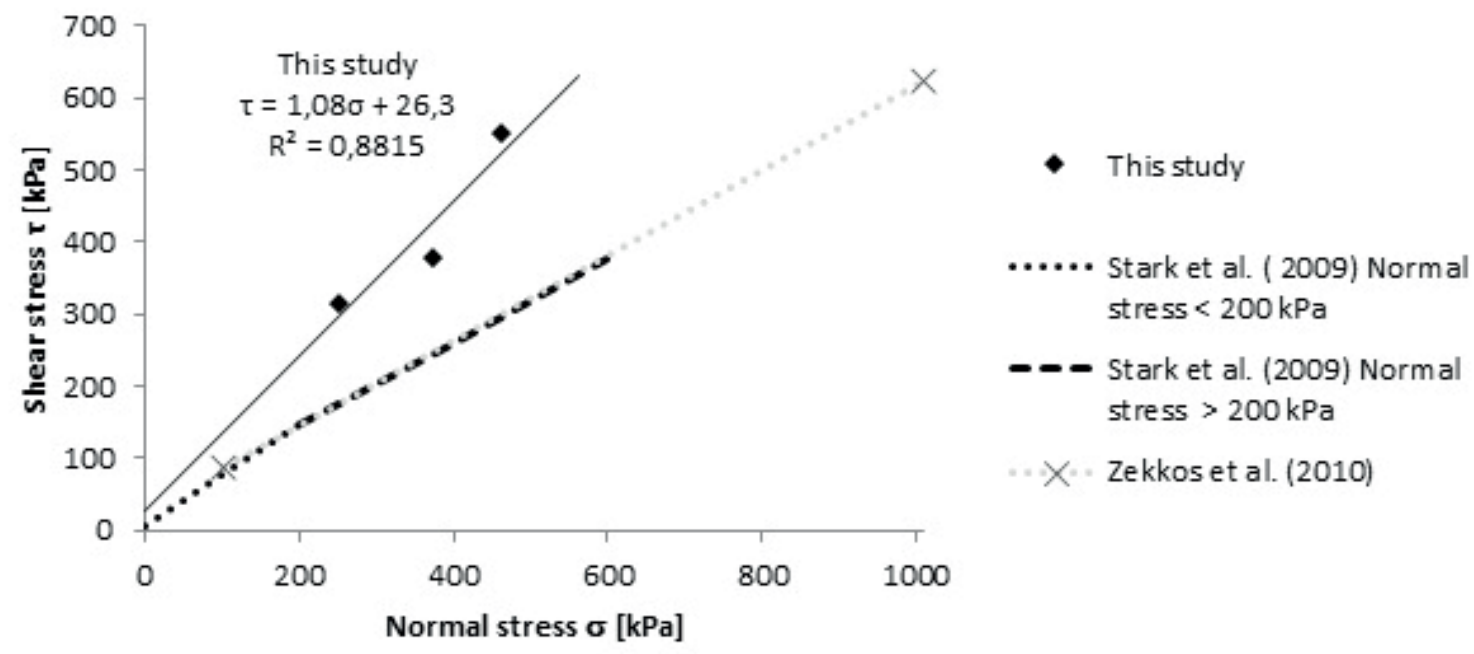

FIGURE 6: Shear strength envelope for USFMS and results from previous studies. R2 denotes the coefficient of determination in the linear regression formula. 
demonstrate the ability of USFMS to absorb a high quantity of water - a good draining system is therefore mandatory to avoid the risk of pore water pressure increase in the landfill.

Turer and Turer (2011) adopted a simplified slope stability approach for the purpose of developing slope stability charts for use in analysis of uncontrolled waste dumps. These can be assumed to yield the worst-case scenario for USFMS. Analysis is performed using the shear strength envelope according to Stark et al. (2009) and unit weight equation of Choudhury and Savoikar (2009), based on the assumption that the failure plane passes through the toe of the slope. To assess USFMS input data comprised a slope height of $35 \mathrm{~m}$, safety factor of 1.5 , bulk density measured at $700 \mathrm{kPa}$ corresponding to unit weight of USFMS at $35 \mathrm{~m}$ depth, and a pore water pressure ratio of 0.3 . This pore water pressure corresponds to half the fill height being water saturated. As pore water pressure rises the effective stress decreases. A decrease in effective stresses will result in poorer stability. With regard to USFMS, simplified slope analysis yields a critical slope angle around $18^{\circ}$. Swedish EPA (2004) recommends a slope angle between 1:2 $\left(\sim 26.6^{\circ}\right)$ and $1: 3\left(\sim 18.4^{\circ}\right)$ in the final cover. USFMS features a higher shear strength and a higher unit weight, which contributes to a better stability than that recommended by simplified slope analysis. Moreover, the results underline the importance of ensuring an effective draining system.

\subsubsection{Settlements}

Total settlements are divided into primary- and secondary settlements. Primary settlement is affected by load, which in turn depends prevalently on fill height and waste density. Secondary settlements are produced by mechanical creep and biodegradation. Creep is largely caused through particle stiffness, with biodegradations being linked to chemical composition of the materials, moisture, and temperature.

Compression ratio $\mathrm{C}_{\mathrm{r}}$ is deemed to correspond to primary settlements. The measurements obtained are provided in Figure 7.
Compression ratio detected for USFMS was in the normal range, although lower than that observed in previous studies, see Table 7.

According to Hossain et al (2009), a waste with a high $\mathrm{R}$-value has a lower compression ratio due to the presence of large items that produce a reinforcement effect. R-value is the ratio of particle to equipment size. R-value of the waste studied here was low (0.036) following the shredding process. Shredding may contribute to the presence of more angular particles capable of increasing inter-particle friction. A lower organic material content may likewise contribute to the finding of slightly lower compression ratio than that detected for MSW.

USFMS was in a position to drain upward during compression, therefore, the high water content of USFMS during compaction (TS of $62( \pm 1.1)$ in the compression vessels) likely did not affect the compression ratio.

Unaffected by load, the bulk density for USFMS, $0.65 \mathrm{t} /$ $\mathrm{m}^{3}$ represents the average density of both frozen and unfrozen USFMS. The results of this study reveal how bulk density is affected by transport handling (shaking), thawing and drainage potential. Bulk density and dry density for USFMS under high pressure were found to be higher than those observed in previous studies conducted by Beaven and Powrie (1995) and Hudson et al. (2004). This finding may be explained by waste composition, i.e. a high content of heavy materials such as concrete and tiles, but also due to a higher compression of USFMS. As reported by Beaven and Powrie (1995) and Hudson et al. (2004), waste was compressed to $600 \mathrm{kPa}$ and $463 \mathrm{kPa}$, respectively. According to Stoltz et al. (2010) a normal compact density for American MSW is 1.6-1.65 ton $/ \mathrm{m}^{3}$. USFMS features a lower organic material content due to mechanical separation and is thus heavier.

In the $3^{\text {rd }}$ compression round 20 compression intervals of $60-80 \mathrm{kN} \sim 305-410 \mathrm{kPa}$ were used, aiming to simulate a compactor working at a landfill. There was no visible difference in compression after the 20 compression intervals.

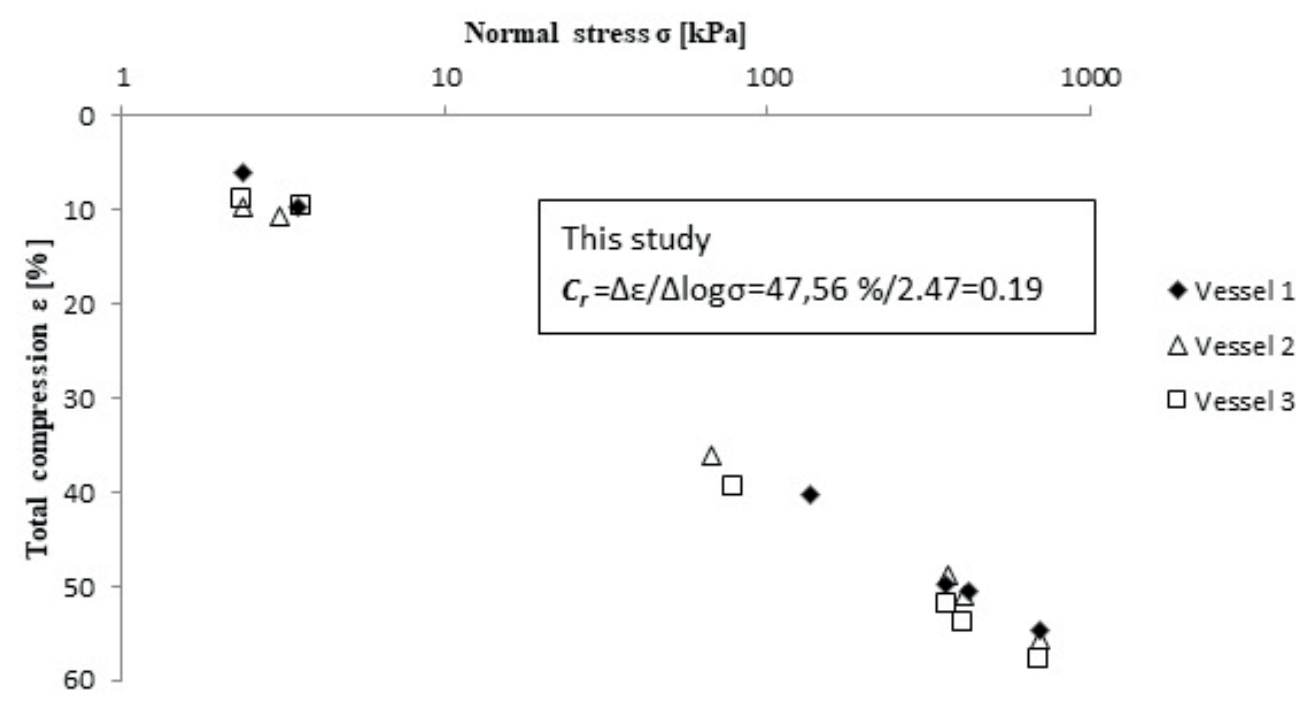

FIGURE 7: Total compression $\varepsilon[\%]$ as function of normal stress $\sigma$ [kPa] in log scale for the three used cylinders. The compression index $\mathrm{Cr}$ is defined as the slope of the curve. 
TABLE 7: Compressibility of USFMS and different MSW.

\begin{tabular}{|c|c|c|c|c|}
\hline Source & $\begin{array}{c}\sigma \\
{[k P a]}\end{array}$ & $\mathrm{C}_{\mathrm{r}}$ & Method & Comments \\
\hline USFMS & 700 & 0.19 & $\begin{array}{l}\text { See Chapter } \\
2 \text {. }\end{array}$ & \\
\hline Reddy et al. (2009) & 750 & $\begin{array}{l}0.24- \\
0.33\end{array}$ & $\begin{array}{l}\text { Oedmeter } \\
\text { test }\end{array}$ & $\begin{array}{l}\text { Fresh MSW. Estimated maximal normal stress from a graph. Different } \\
\text { water content. }\end{array}$ \\
\hline Stoltz et al. (2010) & $\begin{array}{l}140- \\
300\end{array}$ & 0.31 & $\begin{array}{l}\text { Oedmeter } \\
\text { test }\end{array}$ & Fresh MSW. Shredded before testing. maximal waste size $0.07 \mathrm{~m}$. \\
\hline Hossain et al. (2009) & 1050 & $\begin{array}{l}25.5- \\
34.5\end{array}$ & $\begin{array}{l}\text { Oedmeter } \\
\text { test }\end{array}$ & Fresh MSW. Different R-values*. \\
\hline Reddy et al. (2009) quoted by Hossain (2005) & - & $\begin{array}{l}0.16- \\
0.25\end{array}$ & $\begin{array}{l}\text { Oedmeter } \\
\text { test }\end{array}$ & Fresh MSW. Water saturated. \\
\hline
\end{tabular}

* where the $R$-value is the ratio of particle size to equipment size.

Compared to previous studies investigating MSW (Machado et al., 2012) USFMS is characterized by a smaller grain size. According to Machado et al. (2012), grain size distribution increases in line with landfill age due to degradation of organic material. USFMS contains less organic material than a traditional MSW and grain size distribution will not be affected to the same extent by degradation; the risk of secondary settlements produced by organic degradation is likewise lower than for traditional MSW.

\subsubsection{Deformations over time}

The initial settlements of a UFSFM landfill were estimated from measured unit weights and deformations in the compression vessels. The following assumptions were made:

- A proctor compactor vibrated all waste layers successively applying a normal stress of $40 \mathrm{kPa}$;

- The stress from the final cover is comparatively small and can thus be included in normal stress from the compactor;

- The landfill is divided into one-meter layers and unit weight is assumed to be constant within each layer.
Unit weight is taken as the mean value of bulk density in the three compression vessels. The measured unit weight for normal stress of circa $400 \mathrm{kPa}$ remains unclear as the amount of water that drained from compression vessels was not measured continuously, but was first measured on completion of compression at $700 \mathrm{kPa}$.

Figure 7 shows an increase in unit weight from 7 to 15 $\mathrm{kN} / \mathrm{m}^{3}$ on a par with an increase in normal stress from 0 to $700 \mathrm{kPa}$. Unit weights of all landfill layers were affected by normal stress from a compactor of $40 \mathrm{kPa}$. The trend line from $40 \mathrm{kPa}$ and upwards in Figure 8 was used to calculate unit weight as a function of landfill depth. Unit weight of the top layer was only subjected to $40 \mathrm{kPa}$ and was calculated as $8.432 \mathrm{kN} / \mathrm{m}^{3}$. The weight of the USFMS added to overall unit weight for every subsequent landfill layer as shown in Figure 8 , increasing for a $36 \mathrm{~m}$ landfill from $8.4 \mathrm{kN} / \mathrm{m}^{3}$ at the top to approx. $14 \mathrm{kN} / \mathrm{m}^{3}$ at the bottom.

To calculate deformations throughout the different layers, the curve in Figure 9 was used. This curve describes the compression (\%) measured during compaction of the vessels. Normal stress in each layer is based on unit weight at the corresponding depth. As each layer had pre-

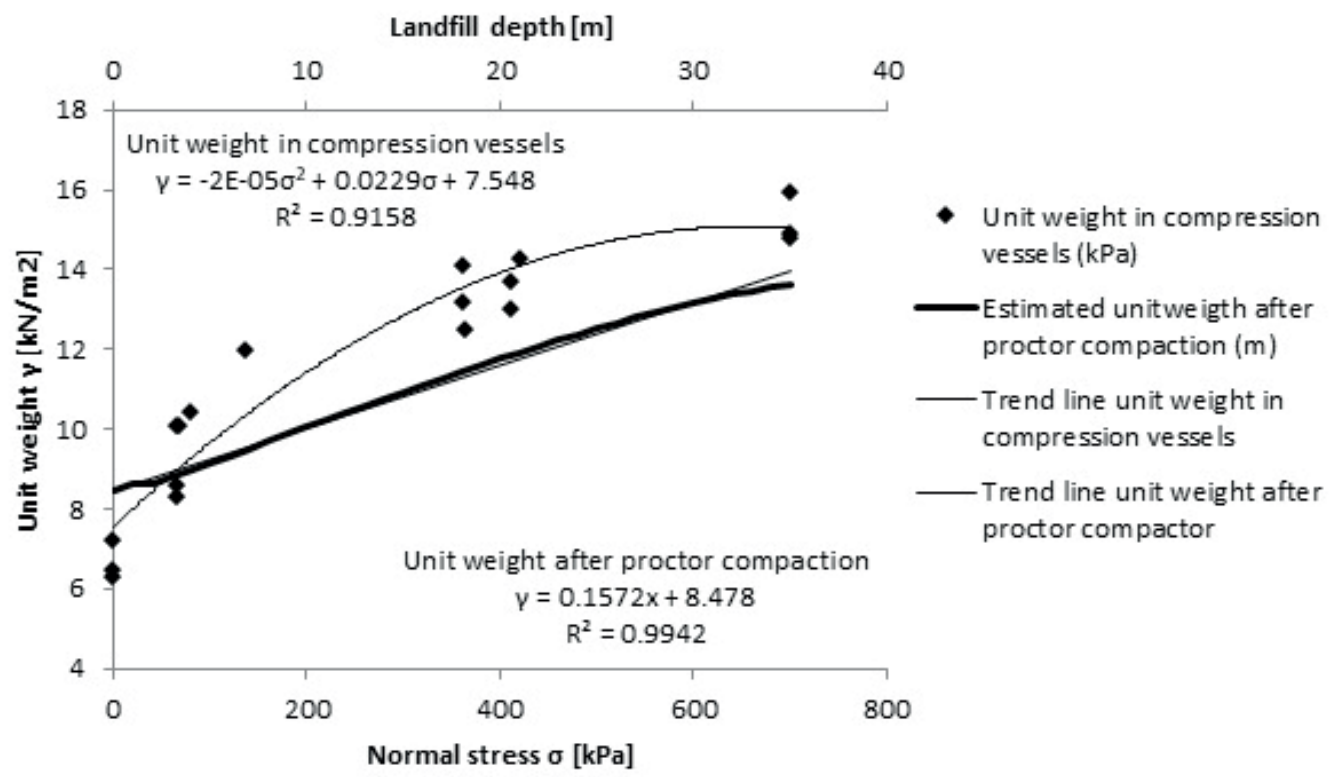

FIGURE 8: Unit weight in the three compression vessels as function of compaction stress and a trend line indicating mean value for the three vessels. Calculated unit weight as function of landfill depth after compaction with $40 \mathrm{kPa}$. 


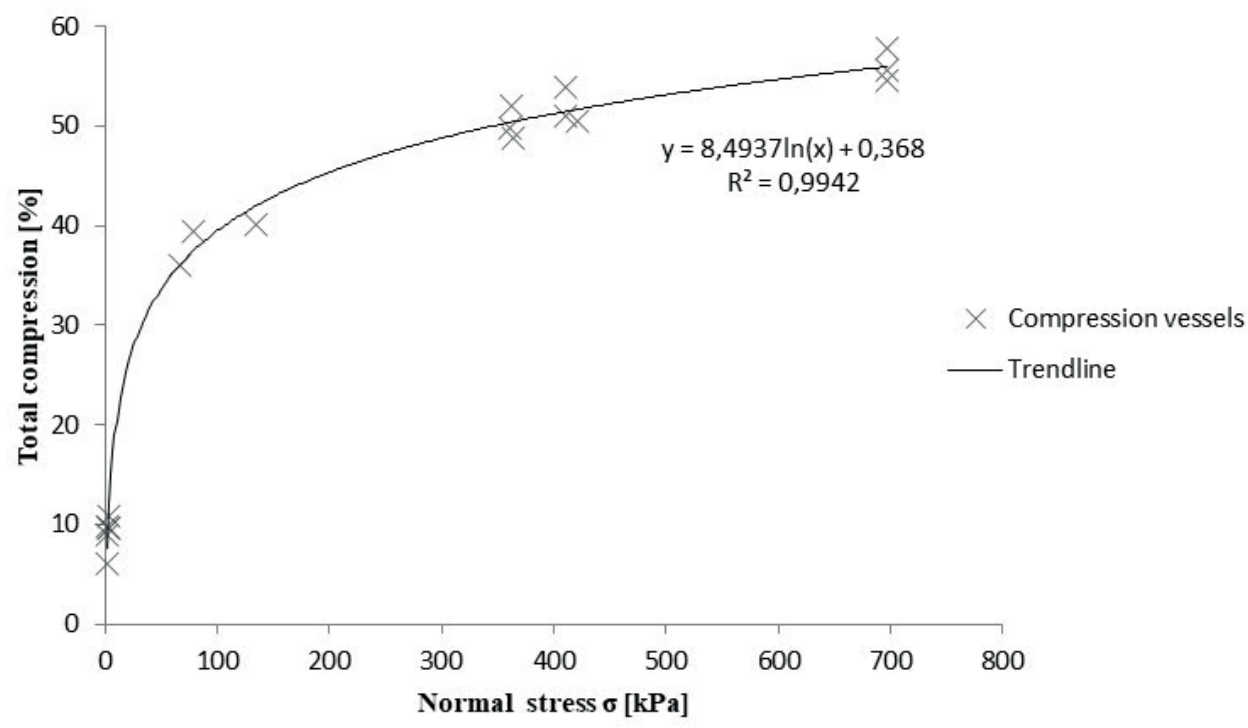

FIGURE 9: Total compression in\% and trend line.

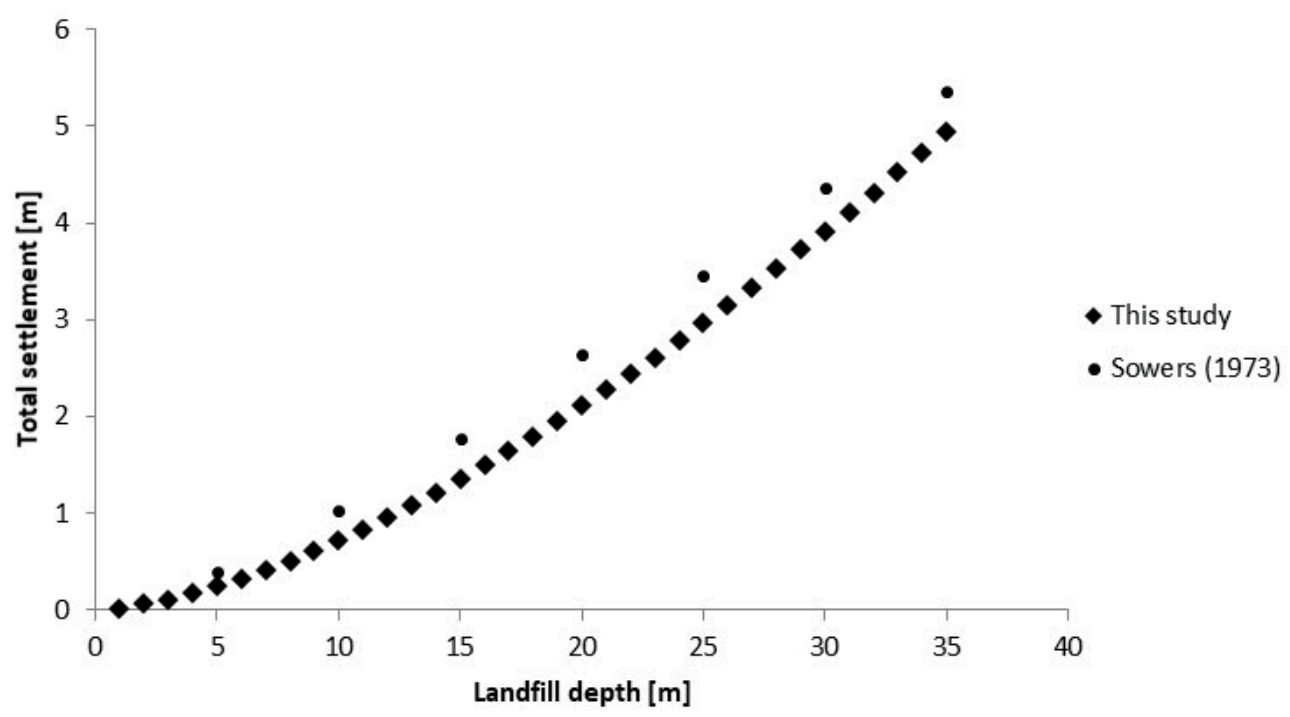

FIGURE 10: Calculated total settlements for a USFMS landfill.

viously been compressed up to $40 \mathrm{kPa}$, only deformations for higher values were used.

The initial settlement calculated using this approach was $4.94 \mathrm{~m}$, corresponding to $14 \%$ - see Figure 10. For the sake of comparison, the initial settlement was also calculated using the method described by Sowers (1973). Using the same unit weight as for UFSFM and $5 \mathrm{~m}$ layers, total settlements amounted to $5.64 \mathrm{~m}$, corresponding to $16.1 \%$.

Maraques et al. (2003) developed models for use in calculating final settlements based on primary compression, mechanical creep and biodegradation. Babu et al. (2011) calculated total settlements of MSW using three models for a landfill height of $30 \mathrm{~m}$. The initial settlement ranged from $18-19.2 \%$, the secondary settlement for creep was 2.3-2.8\%, and biodegradation was $7.9-10.1 \%$. USFMS has a lower organic content than traditional MSW and therefore settlement due to biodegradation may be assumed to be smaller. For USFMS, secondary settlement can be as- sumed as being inferior to $10 \%$, corresponding to $3.5 \mathrm{~m}$ in a $35 \mathrm{~m}$ landfill $\mathrm{m}$.

Estimated total settlement, including initial and secondary deformations, therefore corresponds to approx. 8.5 meters, indicating a reduced tendency to deformation in USFMS compared to traditional MSW.

For wastewater pipes in general, a minimum slope of $1 \%$ is recommended to assist gravity flow. EPA (2000) recommends a $4 \%$ slope in capping systems, and Lagerkvist (2003) recommends $2 \%$. To ensure effective drainage and reduce the risk of build-up of pore water pressure in the landfill due to settlement, drainage layers should be installed at intervals of $12 \mathrm{~m}$ of waste with a $4 \%$ slope.

A possible landfill outline is illustrated in Figure 13.

\subsection{Impact on transportation of liquid phases}

Impact of USFMS on transportation of liquid phases will depend largely on permeability, in turn affected by porosity, 
homogeneity, water holding capacity and other factors.

As shown in Figure 11, particle size distribution of USFMS was fairly even in the range between $0.063 \mathrm{~mm}$ and 16 $\mathrm{mm}$. A comparison of results obtained with the wet sieve with those of the dry sieve highlighted a significantly higher amount of fines, implying that smaller particles adhere to the surface of larger ones in dried material. These fine particles may be mobilized and redistributed in a landfill and cause a further decrease in permeability by clogging of pores.

It is therefore to be expected that voids between larger particles would be filled prevalently by smaller particles having a very small average pore size. Accordingly, a low permeability of $6.7 \times 10^{-9} \pm 2.5 \times 10^{-9} \mathrm{~m} / \mathrm{s}$ at $700 \mathrm{kPa}$, bordering on the permeability of liner materials, was observed. This is comparable to findings reported in previous studies for compressed food wastes (Lagerkvist \& Cossu, 2005). A higher permeability would be obtained on application of lower normal pressure; to this regard, Beaven et al (2008) observed a range of $10^{-8}-10^{-6} \mathrm{~m} / \mathrm{s}$ at $600 \mathrm{kPa}$ for compressed MSW. It should also be kept in mind that the hydraulic conductivity observed here was vertical and counter-directed to the applied pressure. Flow resistance in the horizontal direction was not observed in our test, but it is typically an order of magnitude lower that observed vertically. Hudson et al (2009) reported a hydraulic conductivity 5-7-fold higher in a horizontal compared to vertical direction at an applied stress of $40 \mathrm{kPa}$, and almost 10 -fold higher when the applied stress was increased to $300-500$ $\mathrm{kPa}$.

Thus, it is likely that to a considerable extent both gas and leachate move laterally, and the inclusion of vertical drains may be required.

The high proportion of fines in USFMS also affects the water-holding capacity of the material (field capacity). The large surface area attracts a boundary layer of stagnant water that does not drain during compression. A porosity of $52 \%$ was observed after three months at $700 \mathrm{kPa}$. Both
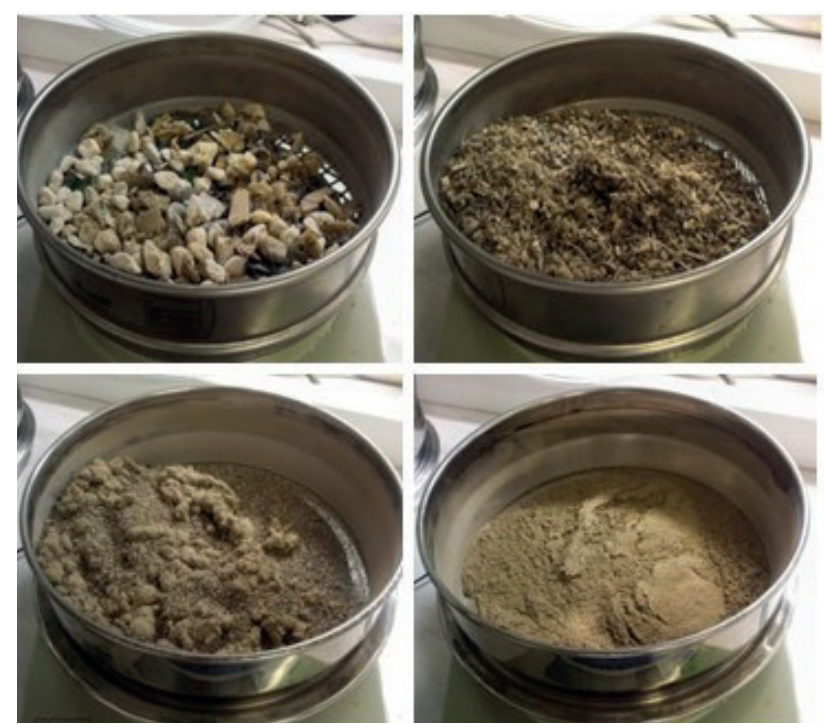

FIGURE 12: Photos from dry sieving. Above: to the left waste $>8$ $\mathrm{mm}$, to the right waste $>2 \mathrm{~mm}$. Below: to the left waste $>0.5 \mathrm{~mm}$, to the right waste $>0.063 \mathrm{~mm}$.

the latter value and field capacity of $54+0.2 \%$ measured several days after compaction, were fairly high compared to values reported in the majority of landfill studies.

No statistical differences were detected in mean values of permeability in the various compression vessels. USFMS therefore may be considered relatively homogenous on a macro-scale as a result of pre-treatment - as also highlighted by the sieving tests. Thus, future local variations in permeability may vary to a lesser degree than waste which has not been mechanically treated and screened prior to landfilling. Based on the low permeability and high field capacity, a water and gas pressure build up may occur at the site of USFMS deposition. The issue of how to avoid stability problems caused by this phenomenon is further discussed in the following section.

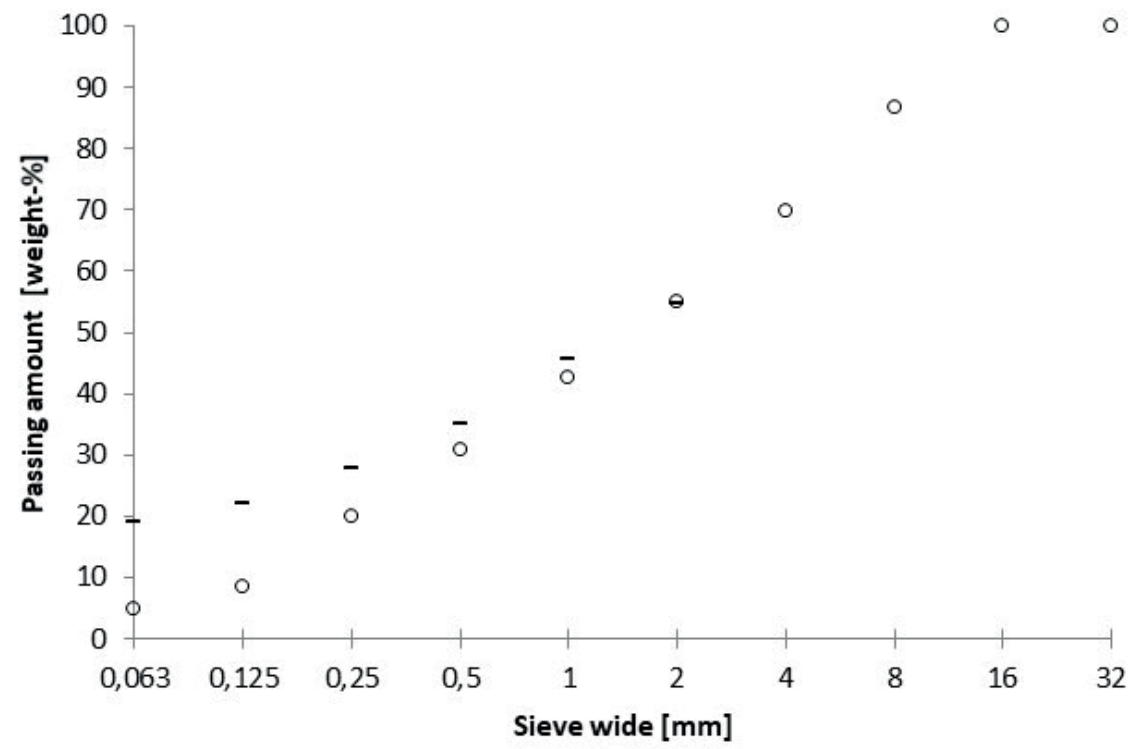

- Dry sieve

- Wet sieve

FIGURE 11: Particle size distribution based on mean values from both dry- and wet sieving. 


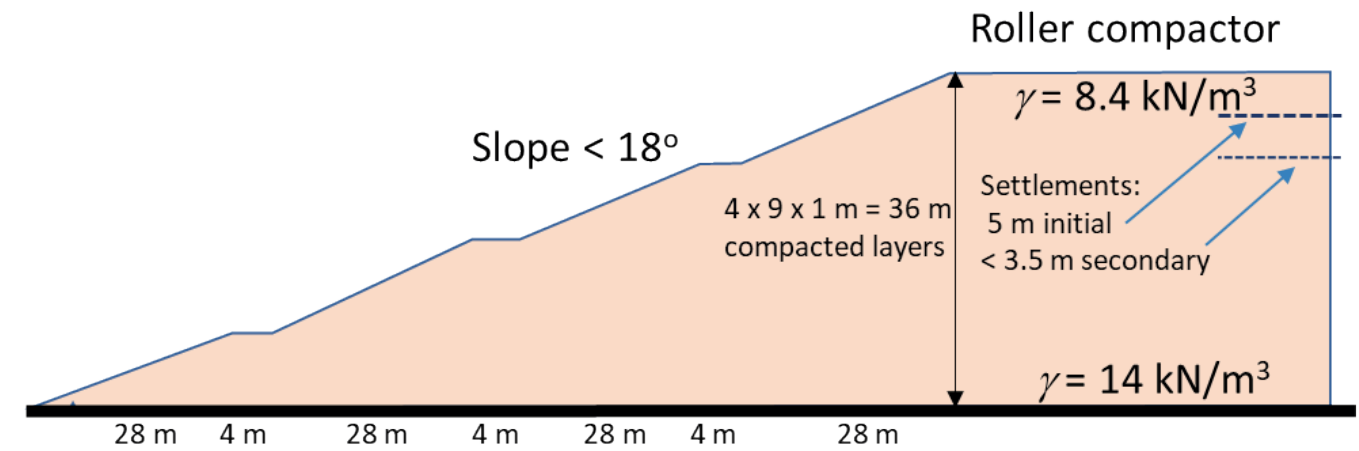

FIGURE 13: Proposed principle outline of a landfill with 36 compacted layers of $1 \mathrm{~m}$ with approximate initial and secondary settlements. Slopes should feature horizontal terraces every 5 to 10 meters to increase stability.

\subsection{Influence on operation, maintenance, installa- tions and treatment systems}

\subsubsection{Gas pressure}

Despite the low gas formation potential, during landfill design the ability of high gas pressure yielded by low permeability and high field capacity of USFMS should be accounted for. The full extent of this scenario is not covered by this study, but stability issues will likely be manifested if adequate precautions (e.g. gas wells, combined drainage layer for gas and water etc.) are not taken. More than one drainage layer should be applied during landfill construction to contrast the build-up of high gas and water pressures.

\subsubsection{Treatment of leachate}

Treatment systems for landfill leachate are based upon different techniques for separation, stabilization and/or degradation of contaminants. This can be achieved through biological, chemical or mechanical methods, depending on types of contaminants and time needed for treatment.

Due to the low permeability of USFMS, an L/S ratio of 10 will not be reached within a time limit of, in order of magnitude, 2500 years (assuming maximum infiltration rate 50 $\mathrm{I} / \mathrm{m}^{2} /$ year according to Swedish legislation for non-hazardous landfills). It is therefore of fundamental importance to identify appropriate treatment based on the mobility of contaminants detected in the leachate at L/S ratio 0.6 (reflecting natural water content in USFMS and actual L/S ratio at a hypothetical discharge today).

Permeability thus obtained corresponds to $200 \mathrm{~mm} /$ year. This implies that in order to meet legislation requirements of $50 \mathrm{~mm} /$ year, approx. $75 \%$ (150 mm/year) of water infiltrating the landfill should be managed directly by the bottom liner, and that the resulting USFMS leachate should undergo treatment due to the presence of organic material, nitrogen and zinc (based on permeability and density at $700 \mathrm{kPa}$ ). Calculations reveal an amount of organic content to be reduced corresponding to $0.4 \mathrm{~kg} /$ ton USFMS per year. With regard to nitrogen and zinc, the corresponding reduction demand is $0.1 \mathrm{~kg} /$ ton USFMS per year, and $1 \mathrm{~g} /$ ton USFMS per year, respectively. It should be noted that these values represent the reduction demands at minimum load of discharged contaminants. An estimation of time needed for treatment can be achieved when comparing results from the column tests with results from agitation batch tests. For a pH-dependent parameter such as zinc, it will take up to about 160 years before the total leachable content has leached out. In reality though, $\mathrm{pH}$ will probably be close to neutral when degradation starts and the redox potential is reduced. Therefore, the discharge of zinc may be lower than shown.

For factors dependent on biology, such as DOC and nitrogen, time needed for treatment should be estimated on the basis of additional assumptions (time period for agitation batch tests to prevent onset of total degradation). Indeed, values obtained for potential gas formation $\left(60 \mathrm{~m}^{3}\right.$ $\mathrm{CH}_{4} / \mathrm{t} \mathrm{VS}$, corresponding to $2.7 \mathrm{~kg} \mathrm{CH}_{4} / \mathrm{t}$ ) indicate that degradation will occur in the landfill. Based on maximum gas formation rate, organic material and nitrogen may need to undergo treatment over several decades.

As shown above, low permeability will result in leaching of contaminants from USFMS over a very lengthy time frame. To avoid the need to ensure operations and maintenance over such a long period, the use of natural passive treatment, such as wetlands, is recommended by the authors. A constructed wetland is often designed to treat leachate and promote the degradation of organic material or transformation of nitrogen. Nitrogen removal may be achieved by a series of methods aimed at promoting nitrification and denitrification. Mobility of any metals present (in this case zinc) will decrease through oxidization and precipitation. A wetland is frequently represented by aerobic pretreatment (e.g. aerated lagoon), that contributes towards reducing the organic load (in terms of BOD). In the case of an aerated lagoon, sludge treatment will also be required. Equalization ponds are also used to manage seasonal fluctuations of nitrogen reduction.

\subsubsection{Compaction Properties}

Bearing capacity is affected by water content, as shown during the proctor compaction test at TS 48\%. Compaction issues have been experienced using MBP-waste (Mechanical and biological pretreated waste) in Germany (Ohlsson et al. (2002), that was solved through the use of a vibrating sheepfoot roller (Ohlsson et al. (2002). Proctor compaction test at TS $64 \%$ showed good compaction properties.

During subsampling, the angle of repose was measured. USFMS was frozen and behaved as a granular mate- 
rial with an angle of repose of $31.7^{\circ}$, similar to a moraine. In the laboratory, the angle of repose was also studied on a material compressed to $700 \mathrm{kPa}$. When digging in the material, even a vertical angle remained stable.

\subsubsection{Indication for design}

A simplified sketch of a landfill is shown in Figure 13. To meet stability requirements, slopes should also feature horizontal terraces every 5 to $10 \mathrm{~m}$. Terraces may also be used during road construction. The important issue of drainage and associated risk of clogging should also be addressed.

Infiltration during heavy rainfall may result in a risk of stability issues:

\subsection{Aftercare and post-operational implications}

In comparison to a landfill containing mixed residual wastes, a USFMS monofill will provide more uniform properties. Thus, the risk of differential settlements and subsequent damage to the final cover will likely be mitigated.

Low permeability of the materials and slow bioconversion processes will imply a need to manage leachate contamination for several decades following covering and completion.

Accordingly, post-treatments such as aeration may also be hampered for the same reason, whilst low gas generation should enhance the feasibility of passive treatments.

\section{CONCLUSIONS}

The following answers are given to the questions in the introduction.

How high is the pollution potential of the under sieve fraction of mechanical sorting, USFMS, in a landfill environment?

- Is it biologically stable? - Yes, it is almost stable, although featuring a high carbon content (total oxidable carbon, TOC $\approx 150 \mathrm{~g} / \mathrm{kg}$ total solids)

- How might it contribute to landfill emissions? - Emission potential is present in both gas and liquid phases; however, given the slow degradation rate and low permeability of the material, only low intensity emissions are expected, which may promote the use of passive treatment methods. The exception would be run-off from surfaces on which shredding and intermediate material storage is carried out

- What kind of pre-treatment could be applied? - Additional separation of degradable organics, washing or hydrothermal carbonation could be considered. However, additional costs may rise beyond the impact.

How should the properties of USFMS be considered in landfill design and operation?

- Impact on stability (slope stability, settlement etc.) High shear strength combined with a lower compression ratio than standard MSW and a well-graded material will contribute towards ensuring good stability and decreasing risk of slides and settlements. A low organic content implies a limited degree of degradation, thus reducing the risk of differential settlements. However, the most critical mechanical property is represented by low permeability, which may result in stability issues in the presence of a build-up of pore water pressure due to ineffective drainage.

- Impact on transport of liquid phases - Gas and leachate may move laterally, which may require for the inclusion of vertical drains.

- Influence on installations and treatment systems. Drainage layers for gas and water should be provided.

- Implications for aftercare and post-operation usage - There is little risk of differential settlements and damage to the final cover but there may be a need to manage leachate contamination for several decades following covering and completion.

In addition to the answers to the questions, the following conclusions could be reached:

- The total content of several metals exceeded guideline values issued by the Swedish Environmental Protection Agency for less sensitive land use. Thus, in the present study, mechanically treated wastes were not indicated for use as construction material for off-site applications. Due to its high water retaining capacity, it could be used in a protective layer above a liner system for supply of water to plants and demotivating deeper root penetration.

It is likely that the amount of similar waste will increase as more processing and material recovery is undertaken. It does not fit well into existing waste management systems, it does not burn well and it contains more organic carbon than what present limit values prescribe for landfilling. Landfilling is still the realistic option, but it must be shown that it can be done with rather limited environmental impacts, which our study indicates.

\section{ACKNOWLEDGEMENTS}

This work was sponsored by RagnSells AB, Anders Kihl at Ragn-Sells $A B$ is also acknowledged for help and advice when performing the study. For assistance with the testing and performance on site at Högbytorp, the Authors wish to thank Paul Würtzell and Catarina Thörngren. Help with the sampling by Anders Gustavsson is also acknowledged, as is help from laboratory staff at LTU.

\section{REFERENCES}

Andersson, E. \& Jobs, M. (2013) Mekanisk och biogeokemisk karaktärisering av mekaniskt upparbetad deponirest vid Ragn-Sells Avfallsbehandling AB:s avfallsanläggning Högbytorp i Upplands Bro,Luleå University of Technology.

Babu, G.L.S, Reddy, K. R. \& Chouksey, S. K. 2011. Parametric study of MSW landfill settlement model. Waste Management, Volym 31, Issue 6, p. 1222-1231.

Beaven, R. P., Powrie, W., \& Zardava, K. (2008). Hydraulic properties of MSW. Paper presented at the Geotechnical Special Publication, (209 GSP) 1-43. doi:10.1061/41146(395).

Beaven, R. D. \& Powrie, (1995). Determination of the hydrological and geotechnical properties of refuse using large scale compression cell. SARDINIA '95 - Fifth International Landfill Symposium, pp. 745-760. 
Dewaele, P., Fleming, I. \& Coulter, S., 2011. Waste excavation and screening for reclamation and re-engineering of a municipal landfill site. Proceedings Sardinia 2011, Thirteenth International Waste Management and Landfill Symposium, S. Margherita di Pula, Cagliari, Italy; 3 - 7 October 2011, pp. 851-852.

Choudhury, D. \& Savoikar, P., (2009). Simplified method to characterize municipal solid waste properties under seismic conditions. Waste Management, 29(2), pp. 924-933.

EPA (2000) (Draft) Technical Guidance For RCRA/CERCLA Final Covers, EPA 540-R-04-007, Office of Solid Waste and Emergency Response, Washington DC, USA.

Hossain, M., Gabr, M. \& Asce, F., 2009. The effect of shredding and test apparatus size on compressibility and strength parameters of degraded municipal solid waste. Waste Management, 29(9), pp. 2417-2424.

Hudson, A. P., White, J. K., Beaven, R. P. \& Powrie, W., (2004). Modelling the compression behaviour of landfilled domestic waste. Waste Management, Issue 24, pp. 259-269.

Hudson, A., Beaven, R. \& Powrie, W., (2009). Assessment of vertical and horizontal hydraulic conductivites of household waste in a large scale compression cell. Sardinia 2009 : Twelfth International Waste Management and Landfill Symposium. S. Margherita di Pula, Italy, s.n., pp. 641-642.

ITRC (2017) Incremental Sampling Technology, see section 6.2.2.7 Analytical splitting and subsampling techniques. Interstate Technology \& Regulatory Council, Washington DC, USA.

IWCS (2009) Landfill Reclamation Demonstration Project. A report prepared by Innovative Waste Consulting Services, LCC and submitted to Florida Department of Environmental Protection and Escambia County Division of Solid Waste Management -

Lagerkvist, A. (2003) Landfill Technology, Luleå University of Technology, Technical report 2003:15

Lagerkvist, A., and Cossu, R., (2005) Leachate recirculation : concepts and applications. Sardinia 2005 : Tenth International Waste Management and Landfill Symposium. Cagliari :CISA, Environmental Sanitary Engineering Centre. 12 p.

Machado, S. L. et al. (2012). Evaluation of the geotechnical properties of MSW in two Brazilian landfills. Waste Management, 30, pp. 2579-2591.

Maraques et al. (2003): Marques, A. C. M., Filz, G. \& Monje, O., 2003. Composite Compressibility Model for Municipal Solid Waste. Journal of geotechnical and geoenvironmental engineering, April. pp. 372-378.

Naturvårdsverket (2016): Sveriges avfallsmängder ökar fortfarande (Swedish waste is still increasing. In Swedish) Swedish Environmental Protection Agency, Press realease: http://www. naturvardsverket.se/Nyheter-och-pressmeddelanden/Pressarkiv/Nyheter-och-pressmeddelanden-2016/Sveriges-avfallsmangder-okar-fortfarande/

Ohlsson, T., Flyhammar, P., Bendz, D. \& Bozkurt, S., 2000. "Sardinia '99, Seventh Waste and Landfill Symposium - en sammanställning av aktuell deponiforskning, Stockholm: Naturvårdsverket.

Pitard, F. F. (1989) Pierre Gy's Sampling Theory and Sampling Practice. Florida: CRC Press Inc.
Stark, T. D., Huvaj-Sarihan, N. \& Li, G., 2009. Shear strength of municipal solid waste for stability analyses. Environ Geo, Volym 57, pp. 1911-1923.

Reddy, K. et al., 2009. Geotechnical properties of fresh municipal solid waste at Orchard Hills Landfill. Waste Management, 29(2), pp. 950-959

SGI, 2007. Deponiers stabilitet, Vägledning för beräkning, Linköping: Statens geotekniska institut.

Sowers, G. F. (1973) Settlement of waste disposal fills, proc $8^{\text {th }}$ ICSMFE, Moscow, 2: 207-211.

Stoltz, G., Gourc, J.-P. \& Oxarango, L., 2010. Characterisation of the physicomechanical parameters of MSW. Waste Management, Volym 30, pp. 1439- 1449.

SS 027109, 1994. Geotekniska provtagningsmetoder - Packningsegenskaper - Laboratoriepackning, s.l.: Swedish Standards Commission.

SS-EN 12457-4, 2003. Karaktärisering av avfall - Laktest - Kontrolltest för utlakning från granulära material och slam, s.l.: Swedish Standards Commission.

SS-EN 13137, 2001. Karaktärisering av avfall - bestämning av totala mängden organiskt kol i avfall, slam och sediment, s.l Swedish Standards Commission.

SS-EN 14346, 2007. Karaktärisering av avfall-beräkning av torrhalt baserad på torrsubstans och vatteninnehåll, s.l.: Swedish Standards Commission.

SS-EN 15169, 2007. Karaktärisering av avfall - bestämning av glödförlust vid upphettning av avfall, slam och sediment, s.l.: Swedish Standards Commission.

SS-EN 933-1, 2012. Ballast - Geometriska egenskaper- - Del 1: Bestämning av kornfördelning - Siktning., s.I.: Swedish Standards Commission.

SS-ISO 11277 , 2001. Markundersökningar - bestämning av kornstorleksfördelning i mineraldelen av jord - sikt- och sedimentationsmetod., s.l.: Swedish Standards Commission.

Swedish EPA, 2004. Handbook 2004:2, Landfilling of waste. NFS 2004:5.

Svensk standard, 1994. Geotekniska provtagningsmetoder Packningsegenskaper - Laboratoriepackning. Stockholm: Swedish Standards Commission.

Turer, D. \& Turer, A., 2011. A simplified approach for slope stability analysisof uncontrolled waste dumps. Waste Management and research, 29(2), pp.146-156.

USEPA (1994a) Trace Elements in Water, Solids, and Biosolids by Inductively Coupled Plasma-atomic Emission Spectrometry. U.S. Environmental Protection Agency.

USEPA (1994b) Determination of Trace Elements in Waters and Wastes by Inductively Coupled Plasma - Mass Spectrometry. Cited 155 times. U.S. Environmental Protection Agency.

Zekkos, D. et al., 2006. Unit Weight of Municipal Solid Waste. Journal of geotechnical and geoenvironmental engineering, 132(10), pp. 1250-1261.

Zekkos, D. et al., 2010. Large-scale direct shear testing of municipal solid waste. Waste Managment, August-September, 30(8-9), pp $1544-1555$ 